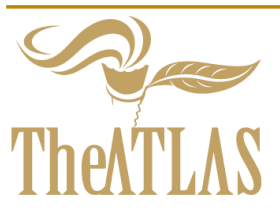

\title{
Transdisciplinary Theory of Mexican Agricultural Knowledge: Semiotics, Communication and Anthropology
}

\author{
Graciela Sánchez Guevara ${ }^{1}$ and José Cortés Zorrilla ${ }^{2},{ }^{1}$ Universidad Autónoma de la Ciudad de México; \\ ${ }^{2}$ Universidad Autónoma Metropolitana-Iztapalapa E-mail: claudetta7@gmail.com; jocz@xanum.uam.mx \\ Received 7 January, 2019; Revised February 28, 2019 Accepted 5 March, 2019 \\ Copyright (C)2019 Graciela Sánchez Guevara and José Cortés Zorrilla. This is an open access article distributed under the \\ Creative Commons Attribution License (https://creativecommons.org/licenses/by/4.0/), which permits unrestricted use, \\ distribution, and reproduction in any medium, provided the original work is properly cited.
}

Available online 7 March, 2019 at www.atlas-journal.org, doi: 10.22545/2019/0118

\section{$\mathrm{T}$}

his paper proposes a transdisciplinary model to explain the process of Mexican agriculture. It presents the results of a transdisciplinary study on wetland agriculture undertaken by the indigenous peoples of Xochimilco and San Gregorio south of Mexico City. The model also engages in a dialogue with three different types of knowledge: the first, corresponding to traditional or empirical knowledge, includes the three levels of reality (complex thinking); while scientific and technical knowledge corresponds to the second level of reality (simple thinking). When the three sets of knowledge create synergy, they produce the great semiotic system that explains their plurality and diversity. When communities self-organize at the ecological level, they conserve the agricultural production, traditions and customs constituting their cultural context. With the help of academic-technological innovation, they preserve their food, educational, sociocultural, and religious identity, and the creation of forms of government in keeping with their idiosyncrasy. These peoples have been able to survive in a world destroyed by genetically modified crops and food imports.

Keywords: Transdisciplinary, levels of reality, agri-culture, anthropology, food identity.

\section{Introduction}

Corn is one; the milpa many. Corn lectures; the milpa converses. Corn is autarkic; the milpa, supportive. Corn is a one-stringed instrument; the milpa is polyphonic Corn is singular; the milpa, plural. Cornfields are disciplined like military parades; the milpa, as joyful and laid-back as carnivals. Corn is sown; the milpa is created. Corn is a crop; the milpa is all of us. (Bartra, 2014: 31) [1]

Agriculture in Mexico City is not a new activity in the urban environment. On the contrary, it is a pro- 
ductive process that contributed to the coherence of the Valley of Mexico, dating back to the foundation of the Great Tenochtitlán as the most important social, economic and ceremonial center in the region (see Figure 1) [2]. The urban nature of agriculture reflects the interests of the city in its evolution over time, particularly in the past fifty years, regarded as the period of its greatest expansion. This is how the modernity of the 20th century, despite its destruction of the environment and its tendency to homogenize, has enabled urban farmers to adapt technology to their own forms of production. This suggests a new rurality, in which territorial expressions derived from agricultural and forestry practices (urban and periurban agriculture) occur most frequently as a result of having established a relationship of reciprocal dependence with the rest of the country [3].

The characteristics of city agriculture in the surroundings of the Metropolitan Area of Mexico City include: (a) a predominance of smallholdings in agricultural activity; (b) restricted use of physical space in livestock activity; (c) recycled materials for the construction of animal housing; (d) garbage, food industry and household waste in animal fodder; (e) intensive use of excreta from dairy cattle as a source of organic matter, macronutrients $(\mathrm{N}, \mathrm{P}, \mathrm{K})$, water and heat for agriculture [4]; (f) a predominance of local knowledge in productive technology and its oral transmission and $(\mathrm{g})$ the sale of products at local or nearby markets (see Figure 2).

Although some researchers have criticized the interest in the agriculture of city, because of its limited contribution to national food production and the regional economy [5], its importance lies in the incorporation of agricultural activities to improve the way of life of vulnerable sectors of the population and to reduce the "ecological footprint" of the city, by using elements regarded as having high waste entropy for productive purposes [6], which bring it closer to the new sustainability goals [7].

Wetland agriculture is the cultivation of gardens on platforms or artificial islets in lakes and swamps. It has existed and persists in various parts of the world and in Mesoamerica, there were examples of intensive agricultural production through topographical modification in wetlands. One of these areas is Lake Pátzcuaro, where evidence of canals and raised crop fields has been found in swamps dating back to the Early Classic period, exploited during the Tarascan Empire [8]. There are also indications of

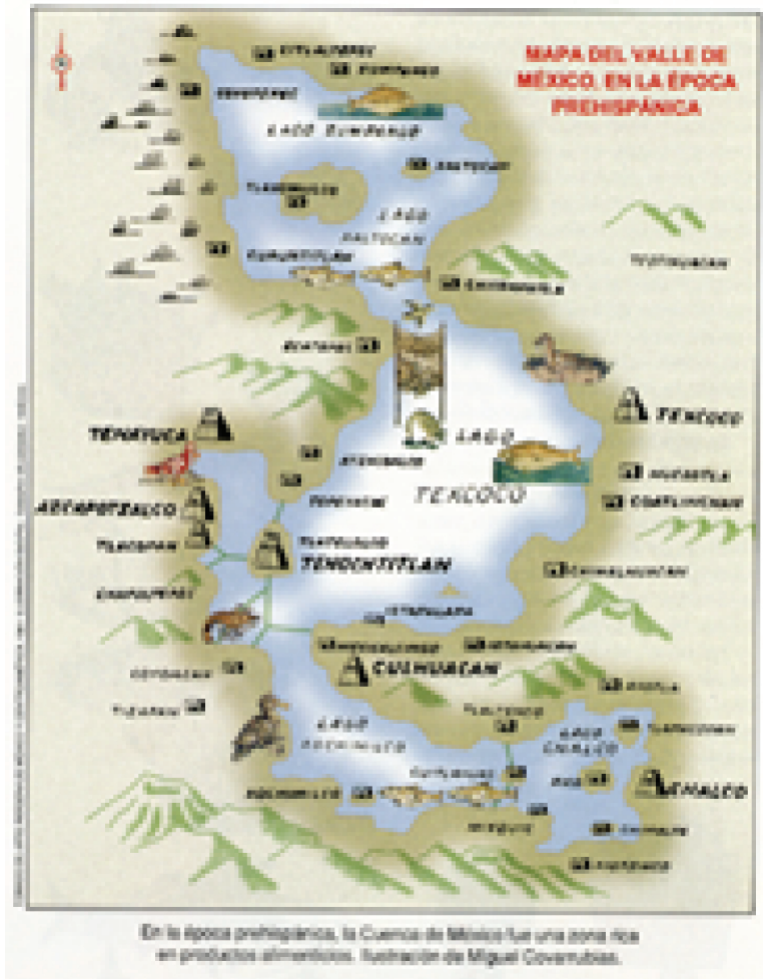

Figure 1: Old map of the Valley of Mexico, painting by Miguel Covarrubias.) https://emedicine.medscape.com/article/ 1875813-overview.

agriculture on raised fields in the central part of the state of Veracruz [9]. The most extensive Mesoamerican area of this type of agriculture, concentrated in the Valley of Mexico Basin, is known as chinampa agriculture.

Wetland agriculture allows excellent yields, since it takes advantage of the conditions that characterize these ecosystems, which combine fertile soils with the constant availability of humidity, meaning that they do not depend directly on the rainfall regime. However, their effective exploitation depends on the development of an agrohydrological regime that is both suitable and sustainable. The system requires in-depth knowledge of the local environment and the adoption of a series of specialized agricultural techniques and care. These techniques vary according to geographical time and space. 


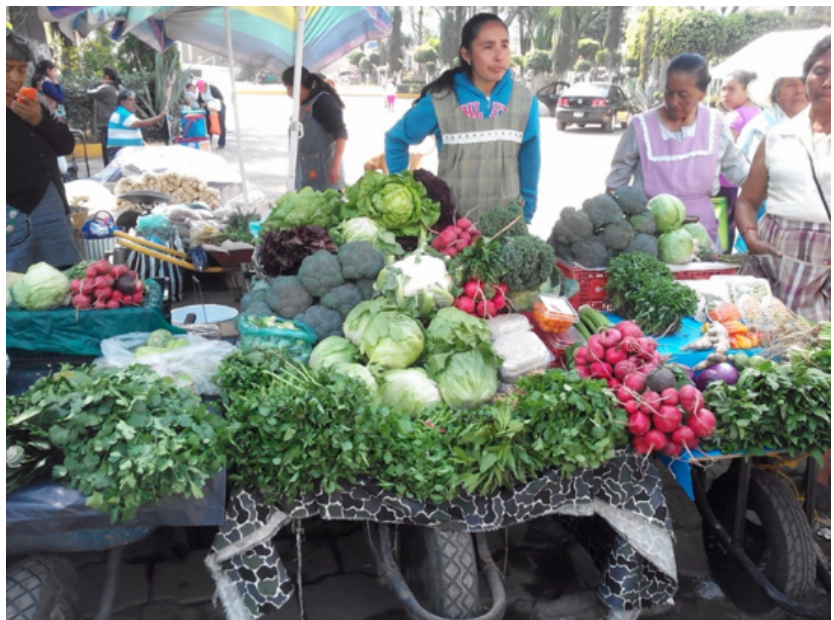

Figure 2: Sale of agro-ecological products Photo: Students of the UAM-I.

\section{Agriculture and Anthropology}

Anthropologists Ángel Palerm and Eric R. Wolf [10] have classified chinampas according to the technology of their construction as "inland chinampas and in-lake chinampas". The first are those that are built on riverside land where the water table is more or less at ground level. In these cases, canals are due so that the water penetrates the islets whose surface remains above the water mirror. Conversely, in-lake chinampas are constructed in shallow waters, as seems to have been the case in most of the Xochimilco and Chalco lakes. Archaeological research conducted in the past 50 years [11] and [12] and descriptions of the construction process provided by observers and scholars in the last century [13] show that the technique that predominated in what is now the region of Xochimilco and Chalco was the "in-lake chinampa". The agricultural process in chinampas can be divided into several stages: sowing, growing, harvesting and transporting produce to the market.

Sowing (see Figures 3, 4 and 5) involves most of the crops in the chinampas that germinate first in seedbeds or seedling nurseries. Seedling nurseries are usually narrow and elongated, with a width of approximately two meters, which facilitates access to their surface from the sides. The base consists of bed of dry plant material covered with a layer of water and mud several centimeters thick. Once the mud dries enough, it is cut lengthwise and widthwise forming a continuous grid of small cube-shaped blocks known as chapines, typically 4 to $6 \mathrm{~cm}$ per side, whose size varies according to the type of plant to be grown. A small hole approximately one centimeter deep is made in the center of each chapin, where several seeds are placed (their number depends on the type of crop) and covered with fertilizer. Once this operation has been completed, if necessary, the storage area is moistened again and covered with grass, large leaves or other protective material, with branches or stones on top to prevent them from being dispersed by the wind. Covering the seedling nursery encourages germination and protects the new plants from the birds, rain, sun, frost, and hailstorms common in the area during the winter months, while germination is encouraged by the heat generated and the decomposition of organic matter in the mud and fertilizer. The covering also serves to condense the humidity that evaporates from the chapines with the heat of the day, which usually happens at dusk. The humidity that has evaporated during the day and returns to the seedling nursery from the cover reduces the need to water it to maintain humidity.

Once the seedlings have germinated and are strong enough, the protective covering is removed and they are left to mature for several weeks until their size requires more space. When the chapines are ready to transplant, the weakest seedlings in each one are removed, leaving only the best ones, which is the reason why several seeds are placed in each chapin. The chapines are then easily separated by hand (since the blocks had been shaped at the outset), and transferred to the definitive field, with the required spacing between them for each crop.

This activity was undertaken in the model chinampa known as "chinampa apantle" of the Civil Association for Ecological Rescue and Civil Development (REDES) and the "Chinampa Apantle" producer group.

Since pre-Hispanic times, chinampas have been extremely productive agro-ecosystems that not only provide food for the population, but also help maintain a series of services such as recharging the aquifer, providing water, cleaning the air and regulating the climate of Mexico City. Like the milpa, in addition to productive aspects, the chinampa preserves the vernacular language, customs, rites and rituals.

One of the goals of REDES AC is to preserve the productive vocation of chinampas through agroecological methods to offer chemical-free food and increase food security through the creation of a "locavore network" (consumption of local products) linking producers in the lake area south of Mexico 


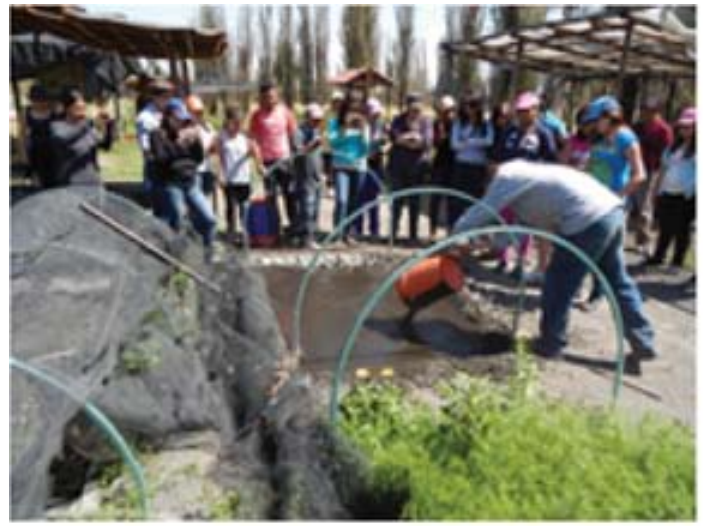

Figure 3: Building a seedling nursery

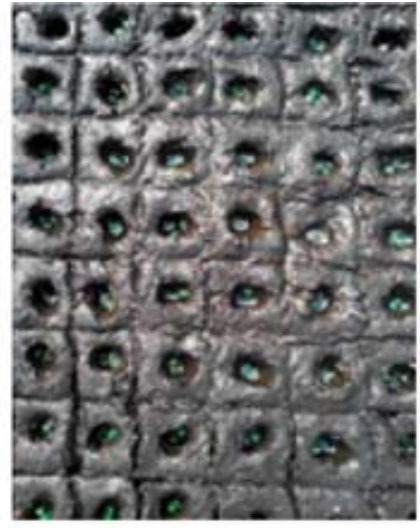

Figure 4: Chapines

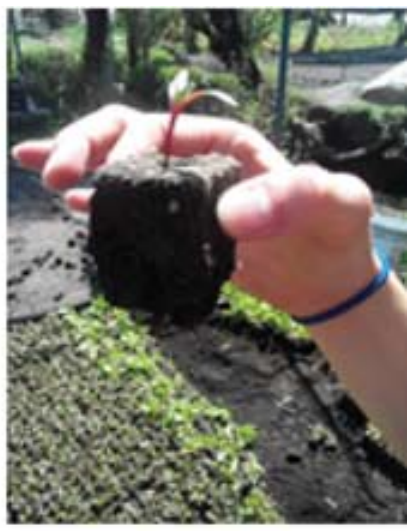

Figure 5: Seedling Photos: students from the UAM-I.

City with consumers. This type of agricultural process offers products for self-consumption as well as for sale, thereby encouraging the conservation of resources and biodiversity.

Agroecological products include aromatic plants such as coriander (Coriandrum sativum), parsley (Petroselim sativum), epazote (Chenopodium ambrosioides), chamomile (Matricaria chamomilla), chives (Allium schoenoprasum), rosemary (Rosmarinus officinalis), dill (Anethum graveolens), mustard leaf (Brassica sp), arugula flower, mint (Mentha spicata) and mint (Mentha $L$ ) and vegetables such as Italian lettuce (Lactuca sativa), butter lettuce (Lactuca sativa var. capitata), and escarole lettuce (Lactuca sativa var. Longifolia), fennel (Foeniculum vulgare), rutabaga (Brassica oleracea), leek (Alium porrum), Brussels sprouts (Brassica oleracea var. Gennifera), cabbage (Brassica oleracea), squash ( $\mathrm{Cu}$ curbita pepo), radish (Raphanus sativus), beet (Beta vulgaris), beet leaf (Beta vulgaris), carrot (Daucus carata var. Sativa), squash (see Figure 6) (Cucurbita sativum L), spinach (Spinacia oleracea), arugula (Eruca sativa), cabbage (Brassica oleracea var. Capitata), celery (Apium graveolens), Swiss chard (Beta vulgaris var. Cicla) (see Figure 7), edible greens (Amaranthus hibridus), pigweed (Chenopodium album), huauzontle (Chenopodium nutallia), zucchini flower (Cucurbita sp) and romeritos (Suaeda diffusa), red corn (Zea mays) (see Figure 8).

The chinampas are protected by planters, spaces created by peasants who, through a combination of their empirical knowledge and scientific knowledge, create a set of integral practices that include the use of disease-resistant varieties, biopreparations, trap plants and repellents, in addition to biological and cultural control. In order to control insect pests it is essential to know their biological cycle, their natural enemies, the stage of their development at which damage occurs and when it is most susceptible, so that preventive measures can be used and effective controls carried out. The sustainable management of pests and diseases seeks to apply a set of comprehensive practices to crops designed to keep the pest insect population at a level that is not harmful to urban productive agro-ecosystems. We call this set of knowledge and behavior of flora and fauna biosemiotics. $^{1}$

Planters comprise several plants: lemon verbena (Aloysia citriodora), is a plant in the family Verbenaceae native to South America. it is grown for its aroma, which resembles lemon; citronella (Cymbopogon) a plant native to India, regarded as a pesticide with a non-toxic mode of action. It has powerful antifungal properties; lavender (Lavandula angustifolia). It is soothing and used to cure insomnia, irritability, headaches and stress. It is a disinfectant and used to heal wounds and burns, dry eczema, scales, sunburn, insect bites. An anti-infective, it cures colds, sinusitis and sore throats. It relaxes and soothes pain, reducing contractions and rheumatism, as well as being antiparasitic and useful for controlling lice; Wormwood (Artemisia annua) is a species of the family Asteraceae commonly called sweet wormwood, or Chinese wormwood; rosemary (Rosmarinus officinalis); and daisies (Bellis peren-

\footnotetext{
${ }^{1}$ Graciela Sánchez Guevara and José Cortés Zorrilla (2018), biosemiotic model for food production. The concepts are the product of as yet unpublished works that have been disseminated in several international congresses in 2018.
} 


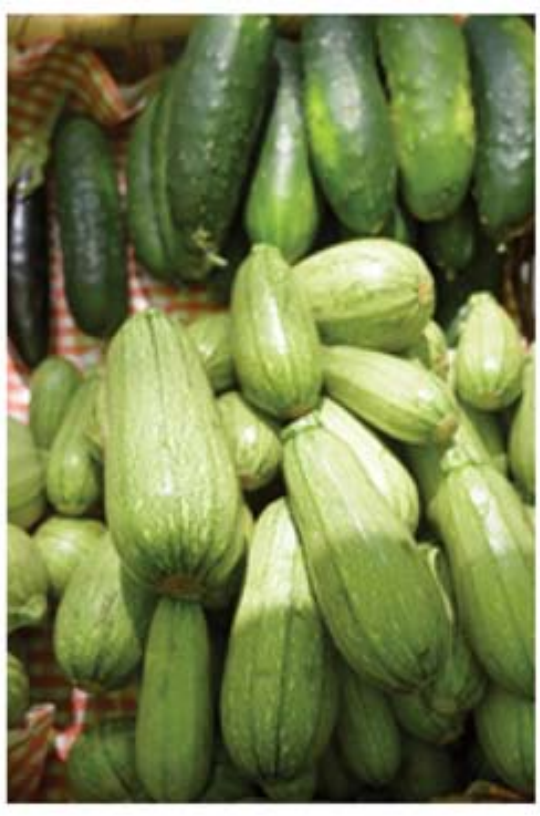

Figure 6: Zucchini and cucumbers

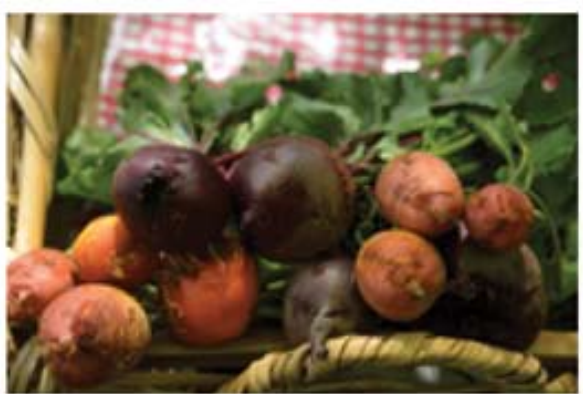

Figure 7: Beets

Photos: Aldo Márquez

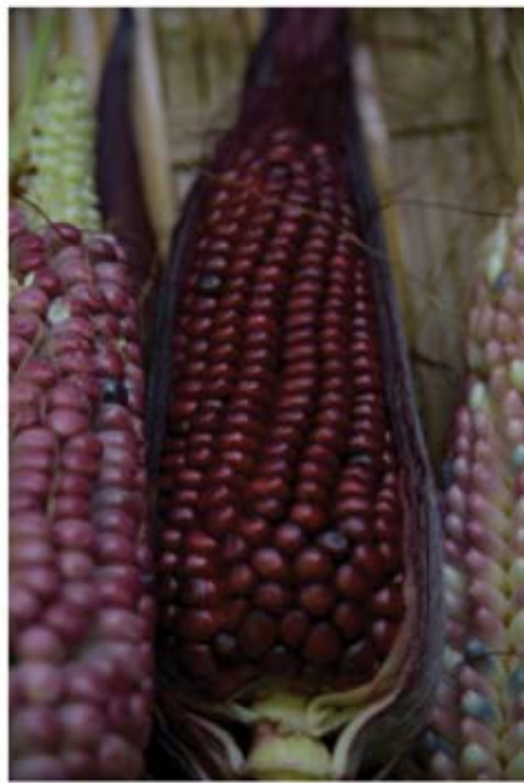

Figure 8: Red corn

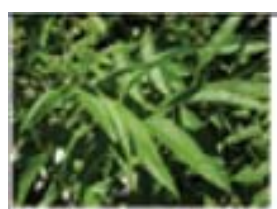

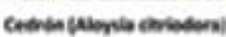

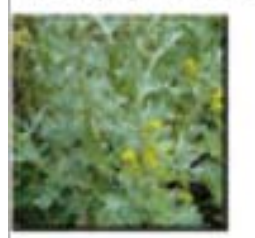

Nento Chtrmale enowl

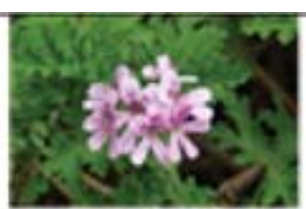

Corente feresentlef

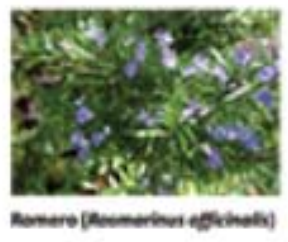

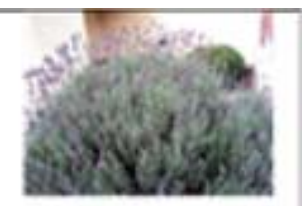
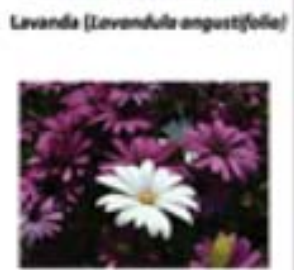

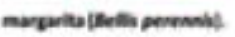

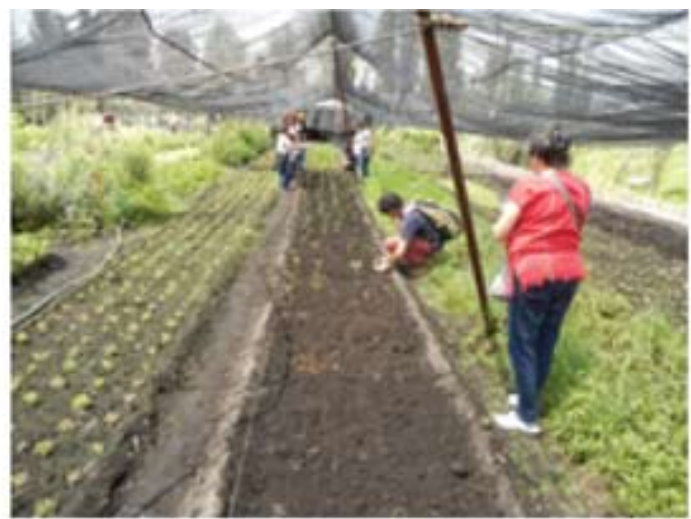

Figure 9: Constituent plants

Figure 10: Chinampa of planters in chinampas

(Photo: Aldo Márquez).

nis), (see Figure 9 and 10).

\section{Agriculture from the Perspective of the Semiotics of Culture and Communication}

The XXI century requires one to conceive of phenomena and problem solving in a complex way, in other words, in an integral way to create a fabric composed of empirical, technical and academic knowledge. It is essential to combine several types of knowledge to recover and enhance traditional agriculture without the need to erode the land, aquifers or the environment as a whole. It is necessary to promote polyculture and eliminate the perverse interests of industrial agriculture [14]. In order to restore proactive, diverse and polyculture agriculture, we propose a transdisciplinary model of the Mexican agricultural process linking three sectors and multiple fields of knowledge. First, the field of empirical knowledge of peasant men and women, second the field of scientific knowledge of academics and third, that of technicians and technologists, respecting the sociocultural practices and socio-historical-political-cultural-ecological and environmental background of each of them. The 
three sectors with their respective knowledge, information and experiences establish intersubjective and intercultural relations in their communication and become dynamic because there is an exchange of concrete cultural inputs such as technology transfer, linked to the symbolic exchange of messages. The socio-cultural communicative exchange between the three sectors defines homogeneity and difference, as well as proximity and distance. This reflects the identity and culture of the subjects identified in each of the components: agricultural, technical and academic. These three components include communicative relations (which) entail the construction of their own individual and collective identity, because people and groups are enriched by, receive, recycle and use them, modifying their ways of being and relating to each other in the short and long term, according to the type of human and social dimension involved [15].

From the perspective of alter-native communication, we propose alternative communication as the resistance of the original peoples that "drives them to a process of re-existence which implies the recognition of cultural diversity and difference, from an alter-native proposal of interculturalizing human society, as a decolonial project" [16] [17]. This communication establishes a dialogue between the three components, where cultural spaces are respected in order to permit a multiple discourse, because they begin from different positions: institutional ones academic and hegemonic knowledge- those of farmers - empirical knowledge - and that of technicians hybridization of academic and empirical knowledge. In this tripartite relationship, symmetrical and asymmetric relations are not denied. On the contrary they mutually recognize and complement each other. In other words, according to Noboa and Albán in relation to the anthropological categories of reexistence and alter-native, we construct the category of alternative communication in the sense in which all the members of a chinampa are recognized in their socio-cultural, agricultural, historical, political, economic and environmental practices. This communication involves a transculturation of knowledge that shifts in language from the hegemonic academic center to the periphery or exteriority of the "other," in other words, the farmer, the technician trained to train producers. This achieves technological transfer without overlooking the knowledge, customs and ways of life of the "other", which not only achieves alternative and alter-native participatory communication, but also communication for another type of development.

From the perspective of the semiotics of culture, Lotman proposes the category of semiosphere, the space outside of which there is no semiosis or production of meaning [18]. The three sectors (see table 1) are considered as three semiospheres which, by breaking down their cultural borders, constitute the great agricultural system, the semiotic universe whose existence makes "the particular act of the sign" a reality. All production, both discursive and semiotic, within the agricultural field also produces a meaning for all members. Since each of the languages and texts referring to the countryside are particular sign acts, we therefore refer to particular semiotics, that is, to the subsystems of the 'great system'. Consequently, the agricultural field represents the "great semiotic system" in which three components coexist and coparticipate: institutions, farmers and technicians in turn make up sign subsystems.

Each semiosphere is characterized and dynamized by its intersubjective relationships and socio-cultural practices, in such a way that the subjects possessing hegemonic-academic-technological knowledge produce discourses and technical-scientific cultural products and transmit them to the group of farmers, which also constitutes the sign subsystem. In this great system, the three semiospheres are considered in an inclusive manner, together with their families in whose intersubjective relationships their rituals, food, music, and all their aesthetic, social, economic, and cultural productions emerge, which, although differentiated by their languages and codes, belong to the same subsystem and semiosphere. This happens because of "the coexistence of discrete verbal languages and iconic languages, in which system the various signs do not form chains, but are engaged in a relationship of homeomorphism, acting as mutually similar symbols" [19].

The discursive semiotic model (see Figure 11) regards the agricultural field as the great system in which diverse subjectivities are incorporated and interrelated. It is an extremely dynamic system in which heterogeneities and homogeneities converge. Convergence is achieved through the border translating filters, which permit the entry of cultural elements so that they can be resemanticized. If this interrelation is achieved recursively and synergistically, then we are talking about the production of 


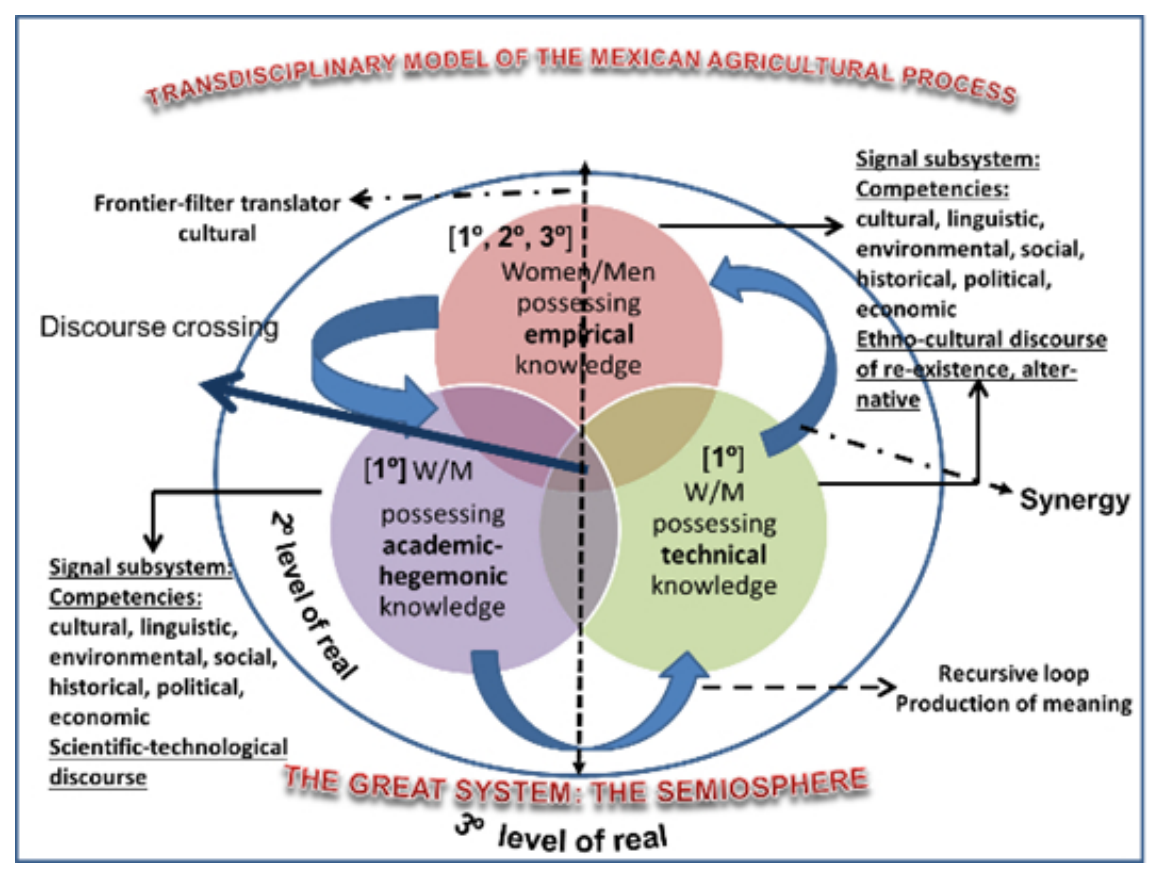

Figure 11: Transdisciplinary Model of the Mexican Agricultural Process.

meaning that exists within each of the components and in their interrelationship with the other two, not only at the level of socio-cultural practices, since meaning is produced and biosemiotics also exists between plants. Planters are a clear example of biosemiotic production, because aromatic and ornamental plants attract insects and bees, and keep them away from the chinampas.

The semiotic-discursive proposal is that they are the subjects possessing empirical knowledge: Farmers with their wives and children who engage in agricultural work, who transmit their knowledge to subjects possessing academic knowledge: scientists and technicians so that they in turn will be able to process this knowledge and convey it to subjects possessing technical knowledge and the latter will return it to the first subjects, in such a way that all the knowledge is integrated, without exclusion. In this exchange of knowledge, the production of knowledge and information is operated and dynamized. The environmental, cultural and historical environment of the countryside and the city cannot be ignored. Consequently, the discursive production of farmers will be different from that of academics. It is therefore important to consider these discursive distinctions, as well as the semiotic production that operates primarily in cultural productions, such as, for example, objects: work tools for the farmer and the academic, used to cre- ate agricultural knowledge. All this set constitutes a complex semiotic-discursive system. In this dialogue of empirical-academic-scientific-technological knowledge, there must in principle be respect of the "other", in such a way that the communication for another type of development effectively contributes to the improvement of the quality of life of members of the communities. This can successfully be achieved if alter-native communication is also respected, in other words, the communication of the "other native", who at the same time re-exists. In other words, the farmer, the rancher, the farm worker and their families who work in chinampas and milpas or other models of agricultural production, must have their beliefs, customs, rites and rituals and worldviews, in short, their way of life respected according to their socio-cultural-historical-environmental-political context, so that they can produce their culture.

\section{Conclusion}

Finally, the dialogue between the knowledge of the three semiospheres proposed, in addition to representing a loop, recursively contemplates the entire complex of activities whatever their nature. In this respect, the semiotic-discursive model in its relation to alternative, alter-native participatory communication, performs its function for another development, which respects polyculture, natural diversity, 
through an articulated plurality of productive strategies, some for self-consumption and others for commercial purposes, including both native seeds and improved ones, which uses both monoculture and polycultures and leading-edge technologies but also ancestral knowledge. What cannot be allowed is for the excessive desire for profit, blind obedience to market signs, the logic of comparative advantages and the industrial agriculture model to continue to destroy agro-ecological diversity and thereby sociocultural plurality [20]. The proposed model hopes to be identified as a transdisciplinary paradigm of synergistic divergence, "the virtuous interplay of activities and vital dimensions is what inspires the milpa, the chinampa, the conuco (small farm), the farm, planting by ecological floors and other traditional farming systems" [21].

\section{Acknowledgements}

We are grateful to the members of REDES AC for their collaboration in this activity, as well as the "Chinampa Apantle" producers group. Special thanks are due to MSc Elsa Valiente Riveros, Ecological Restoration. Director General. Specialist in water resource management with an emphasis on species conservation. Financial and administrative management of ecosystem conservation and participatory community development projects through responsible management and practices. Project management involving academic and government sectors and society in general. Agro-ecological management of chinampas, Management of "Chinampa Apantle" model chinampa, application of agro-ecological techniques and ecotechnique with the aim of recovering traditional agriculture and promoting the conservation of biodiversity in the Xochimilco wetland. http://www.redesmx.org/index.html\#home19 ${ }^{\circ}$ $16^{\prime} 30.4^{\prime \prime} \mathrm{N} 99^{\circ} 06^{\prime} 15.0^{\prime \prime} \mathrm{W}$

Author Contributions: Paper was written collaboratively by two authors.

Conflicts of Interest: The authors declare no conflict of interest.

\section{References}

[1] Bartra, R. (2014). "Por un cambio de paradigmas" en Haciendo milpa. Diversificar y especializar: estrategias de organizaciones campesinas, pp. 15-40.
[2] González, P. (2009). Las chinampas de Xochimilco: periferia ancestral en peligro. En Aguilar, A. G. y Escamilla, I., (Coords.) Periferia urbana, deterioro ambiental y reestructuración metropolitana (pp. 273-289). México, Instituto de Geografía-UNAM, Porrúa.

[3] Ávila, S. H. (2004). La agricultura en las ciudades y su periferia: un enfoque desde la Geografía. Investigaciones geográficas, 53: 98-121.

[4] Losada H. J. Vieyra, R. Soriano R. Bennett, J.Cortés and P. Zavaleta (2001). Assessing the sustainability of a terraced agroecosystem for production of nopal vegetable (Opuntia ficus-indica) in metropolitan Mxico City. American Journal of Alternative Agriculture 16 (3): 98-105.

[5] Ellis, F. y J. Sumberg (1998). "Food Production, Urban Areas and Policy Responses", en World Development, vol. 26, nm. 2, pp. 213-225.

[6] Pezzoli, K. (1998). Human settlements and planning for ecological sustainability. The case of Mexico City, MIT Press, Cambridge.

[7] Clayton, M. H. y N. J. Radcliffe (1996). Sustainability: A Systems Approach. WetviewPress, Colorado.

[8] Fisher C.T.,H.P. Pollard and C. Frederick (1999). Intensive Agriculture and Socio-Political Development in the Lake Patzcuaro Basin;Michoacán,México, in Antiquity, Sept, $1^{\circ}$.

[9] Siemens A.H. (2008). Oriented Raised Fields in Central Veracruz. en American Antiquity, vol.48, no.1, pp 85-102

[10] Palerm A. y E.R. Wolf. (1972). Agricultura y civilización en Mesoamérica,SEP-Setentas 32,SEP, Mexico.

[11] Armillas, P (1971). Gardens on swamps, en Science, 174, No. 4010, November, pp. 653-661.

[12] Sanders W.T. 1976. The Agricultural History of the Basin, in Eric R. Wolf (Comp), The Valley of Mexico Studies in Prehispanic Ecology and Society,School of American Research,Santa Fe, Nuevo México.

[13] Santamaría, M ([1912] 1993). Las Chinampas del Distrito Federal, in Rojas Rabiela [Coord.], La Agricultura Chinampera: Compilación Histrica, Mexico, D.F.: Universidad Autónoma Chapingo.

[14] Bartra, R. (2014). "Por un cambio de paradigmas" in Haciendo milpa. Diversificar y especializar: estrategias de organizaciones campesinas, p. 34.

[15] Alfaro M., RM. La comunicación como relación para el desarrollo. [Una comunicación para otro desarrollo, Calandria, Lima, pp. 27-39]. http://www.aulaintercultural.org/IMG/pdf/rosa_ maria_alfaro.pdf (consultado el 29 de febrero de 2012). 
[16] Albán, A. (2011) "Estéticas decoloniales y de reexistencia: entre memorias y cosmovisiones", en La arquitectura del sentido II. La producción y reproducción en las prácticas semiótico-discursivas. Haidar, J. and Sánchez G. G (Eds.) Col. Investigación PROA, ENAH-INAH, Conaculta,Promep, Mexico, pp. 87-118.

[17] Noboa V., P. (2011). "Discursos, representaciones y prácticas de la colonialidad: la interculturalidad como práctica decolonial" en La arquitectura del sentido II. La producción y reproducción en las prácticas semiótico-discursivas. Haidar, J. y Sánchez G. G (Eds.) Col. Investigación PROA, ENAH-INAH, Conaculta, Promep, México.

[18] Lotman, I. (1996). "Acerca de la semosfera" in La semiosfera I. Madrid: Cátedra, p. 23.

[19] Lotman, I. (1996). "La memoria a la luz de la culturología", in La Semiosfera I. Madrid: Cátedra p. 28.

[20] Bartra, R. (2014). "Por un cambio de paradigmas" in Haciendo milpa. Diversificar y especializar: estrategias de organizaciones campesinas, p. 34 .

[21] Bartra, R. (2014). "Por un cambio de paradigmas" in Haciendo milpa. Diversificar y especializar: estrategias de organizaciones campesinas, p. 37.

\section{About the Authors}

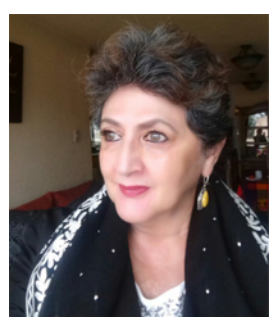

Graciela Sánchez Guevara Doctora en Antropología at UACM, Research experience in Anaális del dicruso, semiótica de la cultura y pensamiento complejo. Coeditora de tres libros. SNI Level 1 researcher member of the National Research System (CONACYT) in México.

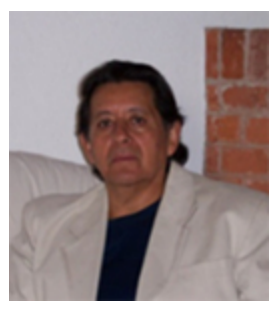

Jos Cortés Zorrilla, Doctor in Animal Production (1993) at UNAM Research experience in Urban Agriculture with academic research corpus (group) Animal. Production Systems and Agricultural \& Livestock Sustainable Development (UAM-I). SNI Level 1 researcher member of the National Research System (CONACYT) in México. 